\title{
Effects of forage type and extruded linseed supplementation on methane production and milk fatty acid composition of lactating dairy cows
}

\author{
K. M. Livingstone, ${ }^{1}$ D. J. Humphries, P. Kirton, K. E. Kliem, D. I. Givens, and C. K. Reynolds ${ }^{2}$ \\ Food Production and Quality Division, Centre for Dairy Research, School of Agriculture, Policy and Development, University of Reading, \\ PO Box 237, Earley Gate, Reading, RG6 6AR, United Kingdom
}

\section{ABSTRACT}

Replacing dietary grass silage (GS) with maize silage (MS) and dietary fat supplements may reduce milk concentration of specific saturated fatty acids (SFA) and can reduce methane production by dairy cows. The present study investigated the effect of feeding an extruded linseed supplement on milk fatty acid (FA) composition and methane production of lactating dairy cows, and whether basal forage type, in diets formulated for similar neutral detergent fiber and starch, altered the response to the extruded linseed supplement. Four mid-lactation Holstein-Friesian cows were fed diets as total mixed rations, containing either high proportions of MS or GS, both with or without extruded linseed supplement, in a $4 \times 4$ Latin square design experiment with 28 -d periods. Diets contained $500 \mathrm{~g}$ of forage $/ \mathrm{kg}$ of dry matter (DM) containing MS and GS in proportions (DM basis) of either 75:25 or 25:75 for high MS or high GS diets, respectively. Extruded linseed supplement $(275 \mathrm{~g} / \mathrm{kg}$ ether extract, DM basis) was included in treatment diets at $50 \mathrm{~g} / \mathrm{kg}$ of DM. Milk yields, DM intake, milk composition, and methane production were measured at the end of each experimental period when cows were housed in respiration chambers. Whereas DM intake was higher for the MS-based diet, forage type and extruded linseed had no significant effect on milk yield, milk fat, protein, or lactose concentration, methane production, or methane per kilogram of DM intake or milk yield. Total milk fat SFA concentrations were lower with MS compared with GS-based diets (65.4 vs. $68.4 \mathrm{~g} / 100 \mathrm{~g}$ of FA, respectively) and with extruded linseed compared with no extruded linseed (65.2 vs. $68.6 \mathrm{~g} / 100 \mathrm{~g}$ of FA, respectively), and these effects were additive. Concentrations of total trans FA were higher with MS compared with GS-based diets (7.0 vs. $5.4 \mathrm{~g} / 100 \mathrm{~g}$ of $\mathrm{FA}$, respectively) and when

\footnotetext{
Received October 17, 2014.

Accepted February 25, 2015.

${ }^{1}$ Present address: Human Nutrition Research Centre, Institute of Cellular Medicine, Newcastle University, Newcastle upon Tyne, NE4 5PL, United Kingdom.

${ }^{2}$ Corresponding author: c.k.reynolds@reading.ac.uk
}

extruded linseed was fed (6.8 vs. $5.6 \mathrm{~g} / 100 \mathrm{~g}$ of FA, respectively). Total n-3 FA were higher when extruded linseed was fed compared with no extruded linseed (1.2 vs. $0.8 \mathrm{~g} / 100 \mathrm{~g}$ of $\mathrm{FA}$, respectively), whereas total $\mathrm{n}-6$ polyunsaturated FA were higher when feeding MS compared with GS (2.5 vs. $2.1 \mathrm{~g} / 100 \mathrm{~g}$ of FA, respectively). Feeding extruded linseed and MS both provided potentially beneficial decreases in SFA concentration of milk, and no significant interactions were found between extruded linseed supplementation and forage type. However, both MS and extruded linseed increased trans FA concentration in milk fat. Neither MS nor extruded linseed had significant effects on methane production or yield, but the amounts of supplemental lipid provided by extruded linseed were relatively small.

Key words: methane, forage type, linseed, milk fatty acid

\section{INTRODUCTION}

Currently, interest is considerable in developing management practices to reduce methane emissions attributable to ruminant meat and milk production, and numerous dietary strategies may be effective in reducing methane production or yield (methane per unit feed DMI). Previous studies have shown that replacing dietary ADF or NDF with starch (Mills et al., 2001), reducing NDF intake (Aguerre et al., 2011), and replacing grass silage (Reynolds et al., 2010) or alfalfa silage (Hassanat et al., 2013) with maize silage (MS) can reduce methane yield, but the effects are not consistent. In growing beef cattle, effects of feeding MS as a replacement for grass silage (GS) on methane yield varied from positive to negative over the course of the experiment (Staerfl et al., 2012). In lactating dairy cows, incremental replacement of alfalfa silage with MS had quadratic effects on methane production and yield such that methane production was higher when the silages were fed as a 50:50 mixture (Hassanat et al., 2013). Somewhat similarly, incremental replacement of GS with MS had a quadratic effect on methane production but linearly decreased methane yield in lactating dairy cows (van Gastelen et al., 2015). 
In addition to effects of forage type and composition, the reducing effects of a variety of supplemental dietary lipids on methane production, yield, or both have been demonstrated in cattle and sheep (e.g., Beauchemin et al., 2008; Grainger and Beauchemin, 2011), with the longer chain PUFA shown to be particularly effective in some studies (Blaxter and Czerkawski, 1966; Clapperton, 1974) but not in all experiments (Grainger and Beauchemin, 2011). Lipids in the diet provide ME while replacing fermentable substrates that contribute to methane synthesis in the rumen. In addition, rumenavailable MUFA and PUFA provide an alternative to methane synthesis for hydrogen disposal by rumen archaea, as well as having direct effects on rumen microflora that reduce methanogenesis (Beauchemin et al., 2008). It has previously been reported that feeding supplemental linseed oil as free oil or crushed or extruded linseed reduced methane production and yield of lactating dairy cows, but DMI and milk yield were also reduced (Martin et al., 2008).

Another topic of interest is developing dairy cow feeding strategies that reduce milk fat concentrations of SFA because dairy fat is a substantial dietary source of SFA in European diets (Givens, 2008). The potential for these particular SFA to raise low-density lipoprotein cholesterol in humans has been implicated as a risk factor for cardiovascular disease (CVD), which is the main cause of premature death in the United Kingdom (Givens, 2008). The cow's diet is a major determinant of milk FA composition (Chilliard and Ferlay, 2004), and studies have shown that alteration of dietary forage type (Ferlay et al., 2006) and inclusion of dietary fat supplements (Kliem et al., 2009) are both means of modifying milk FA composition.

In Northern Europe, MS and GS are conserved forages commonly fed to lactating dairy cows and have been examined in various studies to investigate their differing effect on milk FA composition (Nielsen et al., 2006; Kliem et al., 2008; Samková et al., 2009; van Gastelen et al., 2015). Evidence indicates that feeding cows MS compared with GS has little effect on total SFA but can alter individual SFA concentrations (Kliem et al., 2008; van Gastelen et al., 2015). In contrast, supplemental oilseeds and plant and marine oils lower total SFA significantly, while increasing unsaturated FA (Chilliard et al., 2001; Givens et al., 2009). Increasing MS in the diet can also increase trans FA (Kliem et al., 2008; van Gastelen et al., 2015) through incomplete ruminal biohydrogenation of dietary unsaturated FA, although changes are of lesser magnitude than those increases reported following supplementation with dietary oils (Chilliard et al., 2001). At current intake levels, negative effects of ruminant derived trans on human health are equivocal (Bendsen et al., 2011), but any increases in milk fat should be minimized.

The production response to supplemental lipid is known to vary with forage type (Grainger and Beauchemin, 2011), and the objectives of the present study were to investigate the effects of dietary forage type (MS vs. GS) in diets formulated to contain similar amounts of NDF and starch and feeding an extruded linseed supplement (ELS) on methane production and milk FA composition in mid-lactation multiparous HolsteinFriesian dairy cows, and determine if the response to ELS was affected by forage type.

\section{MATERIALS AND METHODS}

\section{Animals and Diets}

All experimental procedures were licensed, regulated and monitored by the UK Home Office under the Animals (Scientific Procedures) Act, 1996. Four mid-lactation multiparous Holstein-Friesian dairy cows averaging ( \pm SEM) $643 \pm 40 \mathrm{~kg}$ of BW and $60 \pm 8 \mathrm{DIM}$ at the start of the study were randomly allocated to 1 of 4 experimental diets using a $4 \times 4$ Latin square design balanced for first order carryover effects with $28-\mathrm{d}$ periods. Cows were milked twice daily at approximately 0630 and $1630 \mathrm{~h}$. When not restrained for measurements, cows were housed in a cubicle yard with rubber chip-filled mattresses and wood shavings as additional bedding and were milked in a herringbone parlor. While in the cubicle yard, cows were fed individually using an electronic identification controlled pneumatic feed barrier (Insentec, Marknesse, the Netherlands) and drinking water was available ad libitum.

\section{Experimental Design and Treatments}

Throughout the study, cows were fed 1 of 4 experimental diets as a TMR (Table 1) provided for ad libitum DMI (10\% refusals). Basal diets were high MS or high GS diets, with and without supplemental (50 g/ $\mathrm{kg}$ of diet DM) ELS (containing $275 \mathrm{~g}$ of ether extract/ kg of DM; Lintec, BOCM Pauls Ltd., Wherstead, UK), providing 4 treatments in a $2 \times 2$ factorial design. Diets were based on diets used in a previous study (Reynolds et al., 2010) and were formulated to be isonitrogenous and have similar NDF and starch concentrations based on preliminary analyses of available silages and expected composition of concentrates. Animals were fed twice daily receiving two-thirds of their daily allocation in the morning and the remaining one-third in the afternoon. Refused TMR was removed and weighed daily before the morning feeding. 
Table 1. Ingredients and chemical composition of the experimental diets $(\mathrm{g} / \mathrm{kg}$ of $\mathrm{DM}$ unless otherwise stated)

\begin{tabular}{lrrrr}
\hline & \multicolumn{4}{c}{ Treatment $^{1}$} \\
\cline { 2 - 5 } Ingredient & MS & ML & GS & GL \\
\hline Grass silage $^{2}$ & 125 & 125 & 375 & 375 \\
Maize silage $^{3}$ & 375 & 375 & 125 & 125 \\
Cracked wheat & 100 & 100 & 100 & 100 \\
Maize meal & 0 & 0 & 100 & 100 \\
Molassed sugar beet feed & 50 & 50 & 0 & 0 \\
Soybean hulls & 92 & 79 & 98 & 86 \\
Wheat feed & 92 & 60 & 90 & 57 \\
SoyPass & 26 & 26 & 26 & 26 \\
Soybean meal & 62 & 57 & 51 & 46 \\
Rapeseed meal & 43 & 43 & 0 & 0 \\
Molasses & 15 & 15 & 15 & 15 \\
Dicalcium phosphate & 5 & 5 & 5 & 5 \\
Salt & 5 & 5 & 5 & 5 \\
Minerals and vitamins $^{6}$ & 10 & 10 & 10 & 10 \\
Extruded linseed $^{7}$ & 0 & 50 & 0 & 50 \\
\hline
\end{tabular}

${ }^{1}$ Maize silage-based TMR (MS), maize silage-based TMR with extruded linseed (ML), grass silage-based TMR (GS), grass silage-based TMR with extruded linseed (GL).

${ }^{2}$ Containing (g/kg of DM): CP (159), NDF (339), sugars (18.4), and ash (92).

${ }^{3}$ Containing (g/kg of DM): CP (70), NDF (346), starch (344), sugars (13.2), and ash (31).

${ }^{4}$ Rumen bypass soybean meal, Borregaard LignoTech, KW Alternative Feeds, Bury St. Edmunds, UK).

${ }^{5}$ Pioneer Rocksalt, Broste Ltd., Norfolk, UK.

${ }^{6}$ Dairy Direct, Bury St Edmunds, Suffolk, UK.

${ }^{7}$ Lintec, BOCM Pauls Ltd., Wherstead, UK. Declared composition (g/ $\mathrm{kg}$ of DM): CP (196), NDF (295), sugars (41.5), and ash (49.1).

\section{Experimental Measurements and Sample Collection}

Cows were weighed at the beginning of the study and the end of each period. Feed intake was recorded daily. Representative samples of the 4 TMR diets, individual forages (MS, GS), and concentrates (concentrate blends and Lintec) were taken on the last $5 \mathrm{~d}$ of each treatment period, bulked, and stored in sealed bags at $-20^{\circ} \mathrm{C}$. At the end of the trial, bulked samples were thawed, mixed, and split into sub-samples for further analyses. A representative sample of refused feed was taken during the last $5 \mathrm{~d}$ of each experimental period and analyzed for $\mathrm{DM}$ content $\left(100^{\circ} \mathrm{C}\right.$ for $\left.24 \mathrm{~h}\right)$ to determine individual DM intakes. Sub-samples of forages and concentrates were stored frozen at $-20^{\circ} \mathrm{C}$ until analyzed for chemical composition.

Milk yields were recorded daily throughout the study. Milk samples were taken during the last $5 \mathrm{~d}$ of each period and preserved with potassium dichromate (1 $\mathrm{mg} / \mathrm{ml}$; Lactabs, Thomson and Capper, Runcorn, UK) for the determination of milk composition. Additional untreated milk samples were taken on the last day of each period, composited according to yield, and stored at $-20^{\circ} \mathrm{C}$ before $\mathrm{FA}$ analysis.
For the last $5 \mathrm{~d}$ of each period, cows were housed individually in 1 of 2 open-circuit respiration chambers and four 24-h measurements of methane and carbon dioxide production, oxygen consumption, and heat production were obtained as described previously (Reynolds et al., 2014). While in the chambers, cows were restrained using head yokes, bedded using wood shavings on rubber mats, had continuous access to drinking water through drinking bowls, and were milked using a pipeline system.

\section{Chemical Analyses}

Diet components were analyzed for NDF, ADF, OM, $\mathrm{CP}$, water-soluble carbohydrates, starch, and estimated ME concentrations as described previously (Kliem et al., 2013; Reynolds et al., 2014). In addition, oven-dried $\left(60^{\circ} \mathrm{C}\right)$ and milled (1-mm screen) samples of forages and concentrates were analyzed for FA concentration using an adapted one-step extraction-transesterification method as described by Kliem et al. (2013). Based on this method, toluene was used as an extraction solvent, methanolic sulfuric acid $(2 \%, \mathrm{vol} / \mathrm{vol})$ as the methylating reagent, and tritridecanoin (T3882, Sigma-Aldrich Company Ltd., Dorset, UK) in toluene as an internal standard.

Mid-infrared spectroscopy (Foss Electric Ltd., York, UK) was used to determine milk fat, protein, casein, lactose, and urea concentrations and 4\% FCM yield calculated as described by Reynolds et al. (2014). Milk samples were analyzed for FA composition as described by Kliem et al. (2008, 2013). Briefly, samples were thawed in warm water $\left(40^{\circ} \mathrm{C}\right)$, cooled to room temperature, and shaken to ensure homogeneity. Lipid in $1 \mathrm{~mL}$ of milk was extracted using ethanol, diethyl ether, and hexane. Using sodium methoxide in methanol, extracted FA were base-catalyzed transmethylated to FAME, and calcium chloride was used to remove methanol residues. Subsequent FAME samples were separated using a flame ionization detector gas chromatograph (GC 3400, Varian Inc., Palo Alto, CA). Milk fat FAME were identified based on retention time comparisons with a mixture of authentic standards (GLC \#463, Nu-Chek Prep Inc., Elysian, MN; and O4754, O9881, E4762, V1381, Sigma-Aldrich Company Ltd., Dorset, UK) and cross-referencing with published literature. Correction factors, to account for the carbon deficiency in the flame ionization detector response for FAME containing 4- to 10-carbon atoms, were estimated using a reference butter oil of known composition (CRM 164, Bureau of European Communities, Brussels, Belgium). After correcting FAME to FA, all results were expressed as grams per $100 \mathrm{~g}$ of total FA. 
Table 2. Composition of the total mixed rations fed ( $\mathrm{g} / \mathrm{kg}$ unless otherwise stated) on a DM basis

\begin{tabular}{|c|c|c|c|c|c|c|c|c|}
\hline Item & \multicolumn{4}{|c|}{ Treatment $^{1}$} & SEM & \multicolumn{3}{|c|}{$P<^{2}$} \\
\hline $\mathrm{OM}$ & 932 & 937 & 924 & 925 & 2.5 & 0.014 & 0.304 & 0.581 \\
\hline NDF & 320 & 334 & 303 & 308 & 4.9 & 0.006 & 0.115 & 0.383 \\
\hline $\mathrm{ADF}$ & 220 & 218 & 240 & 227 & 4.8 & 0.016 & 0.129 & 0.210 \\
\hline Starch & 223 & 211 & 194 & 186 & 4.1 & 0.001 & 0.078 & 0.632 \\
\hline $\mathrm{ME}, \mathrm{MJ} / \mathrm{kg}$ of $\mathrm{DM}$ & 11.4 & 11.3 & 11.2 & 11.3 & 0.08 & 0.339 & 0.515 & 0.216 \\
\hline \multicolumn{9}{|l|}{ FA } \\
\hline $16: 0$ & 3.05 & 3.52 & 3.11 & 3.39 & 0.052 & 0.575 & 0.003 & 0.195 \\
\hline 18:0 & 0.53 & 0.86 & 0.44 & 0.77 & 0.025 & 0.007 & 0.001 & 0.875 \\
\hline $18: 1$ cis -9 & 4.17 & 5.86 & 3.08 & 4.20 & 0.085 & 0.001 & 0.001 & 0.009 \\
\hline $18: 2 \mathrm{n}-6$ & 9.80 & 10.56 & 8.36 & 9.31 & 0.162 & 0.001 & 0.003 & 0.601 \\
\hline $18: 3 n-3$ & 2.72 & 8.32 & 4.73 & 9.07 & 0.279 & 0.015 & 0.001 & 0.106 \\
\hline
\end{tabular}

${ }^{1}$ Maize silage-based TMR (MS), maize silage-based TMR with extruded linseed (ML), grass silage-based TMR (GS), grass silage-based TMR with extruded linseed (GL).

${ }^{2}$ Probability for the effect of forage $(\mathrm{F})$, extruded linseed $(\mathrm{L})$, or their interaction $(\mathrm{F} \times \mathrm{L})$.

\section{Statistical Analyses}

Results averaged for each cow and sampling period were analyzed using mixed models procedures testing for fixed effects of period, forage, ELS, and forage by ELS interaction and random effects of cow (SAS version 9.2, SAS Institute, Cary, NC). Period by forage interaction was included in the statistical model but removed when declared nonsignificant $(P>0.10)$. Period was treated as a repeated effect within individual cows using the compound symmetry covariance structure, which was found to have the best fit based on Akaike information criterion. Denominator degrees of freedom were calculated using the Kenward-Rogers method. Least squares means are reported, and treatment effects were considered significant at $P<0.10$.

\section{RESULTS}

\section{Dietary Composition and Intake and Milk Yield and Composition}

In comparison with the GS diets, the MS diets contained higher OM, NDF, and starch concentrations $(P$ $<0.02$ ), while $\mathrm{CP}, \mathrm{ADF}$, and ash concentrations were higher for the GS diets $(P<0.020$; Table 2$)$. The MS diets were higher in 18:0, cis-9 18:1, and 18:2n-6 ( $P$ $<0.003)$, and lower in $18: 3 \mathrm{n}-3(P<0.02)$ than the GS diets. The dietary concentration of 16:0 was not affected by forage type $(P=0.575)$. The addition of ELS to the diets increased the concentration of all FA measured $(P<0.003)$, and the increase in cis-9 18:1 was greater for the MS diet. Total FA concentrations were similar in MS and GS diets without added ELS, and were increased by ELS addition to a greater extent with the MS compared with the GS diet (forage by ELS interaction, $P<0.03)$.

Supplementation with ELS had no effect on DMI ( $P$ $=0.31)$, but DMI was higher for MS compared with GS diets $(P<0.10$, Table 3$)$. Intakes of 18:0, cis-9 18:1, 18:2n-6, and total FA were lower on GS than MS diets $(P<0.001$; Table 3$)$. Intake of $18: 3 n-3$ was higher for GS diets $(P<0.001)$, and the increase in 18:3n-3 intake with ELS addition was greater for the MS than GS diets (forage by ELS interaction, $P<0.02$ ). Milk or $4 \%$ FCM yield, milk composition, and milk component yield were not affected by diet forage type or ELS addition (Table 3).

\section{Methane Emission and Respiratory Exchange}

Methane production (L/d) and yield (L/ $\mathrm{kg}$ of DMI) were not affected by diet (Table 4). Similarly, methane production per liter of milk yield was not affected by diet forage type or ELS addition. Cows fed higher MS diets had higher oxygen consumption $(P<0.03)$, carbon dioxide production $(P<0.04)$, and heat production $(P<0.03)$ than when fed higher GS diets (Table 4$)$.

\section{Effect of Forage Type on Milk FA Composition}

Milk fat total SFA concentration was lower when higher MS diets were fed $(P=0.076)$, but no forage type effect was found for most individual milk SFA $(P$ $>0.10)$, with the exception of 13:0 iso $(P=0.034), 13: 0$ anteiso $(P<0.058), 14: 0(P=0.082), 15: 0(P=0.009)$, 
Table 3. Effects of extruded linseed supplementation and dietary forage on DM and FA intake and milk and constituent yield

\begin{tabular}{|c|c|c|c|c|c|c|c|c|}
\hline Item & \multicolumn{4}{|c|}{ Treatment $^{1}$} & SEM & \multicolumn{3}{|c|}{$P<^{2}$} \\
\hline DMI, kg/d & 20.3 & 21.2 & 19.2 & 19.7 & 1.1 & 0.094 & 0.310 & 0.712 \\
\hline \multicolumn{9}{|l|}{ FA intake, $\mathrm{g} / \mathrm{d}$} \\
\hline $16: 0$ & 60.1 & 70.7 & 57.5 & 66.6 & 3.24 & 0.125 & 0.002 & 0.691 \\
\hline $18: 0$ & 11.2 & 18.8 & 9.9 & 16.4 & 0.66 & 0.002 & 0.001 & 0.186 \\
\hline $18: 1$ cis-9 & 62.0 & 96.5 & 47.8 & 75.3 & 3.38 & 0.001 & 0.001 & 0.123 \\
\hline Total FA & 461 & 660 & 403 & 568 & 25.4 & 0.002 & 0.001 & 0.296 \\
\hline \multicolumn{9}{|l|}{ Yield } \\
\hline Milk, kg/d & 36.1 & 37.4 & 35.7 & 35.4 & 1.1 & 0.358 & 0.710 & 0.519 \\
\hline $4 \%$ FCM, $\mathrm{kg} / \mathrm{d}$ & 32.4 & 33.8 & 35.1 & 32.2 & 2.0 & 0.763 & 0.665 & 0.230 \\
\hline Fat, $g / d$ & 1,200 & 1,258 & 1,387 & 1,203 & 125 & 0.510 & 0.528 & 0.244 \\
\hline Protein, $\mathrm{g} / \mathrm{d}$ & 1,143 & 1,199 & 1,149 & 1,126 & 30 & 0.310 & 0.608 & 0.239 \\
\hline Lactose, $\mathrm{g} / \mathrm{d}$ & 1,624 & 1,670 & 1,659 & 1,598 & 93 & 0.851 & 0.941 & 0.589 \\
\hline Casein, $\mathrm{g} / \mathrm{d}$ & 23.5 & 24.0 & 24.4 & 23.8 & 0.5 & 0.276 & 0.805 & 0.134 \\
\hline Urea, mg/dL & 23.2 & 22.1 & 23.1 & 21.1 & 1.6 & 0.651 & 0.264 & 0.708 \\
\hline
\end{tabular}

${ }^{1}$ Maize silage-based TMR (MS), maize silage-based TMR with extruded linseed (ML), grass silage-based TMR (GS), grass silage-based TMR with extruded linseed (GL).

${ }^{2}$ Probability for the effect of forage $(\mathrm{F})$, extruded linseed $(\mathrm{L})$, or their interaction $(\mathrm{F} \times \mathrm{L})$.

and 24:0 $(P=0.010)$, which were lower on MS-based diets compared with GS-based diets (Table 5).

Feeding higher MS diets increased all trans 18:1 isomers $(P<0.06)$, leading to overall higher total trans MUFA $(P=0.009)$ concentrations relative to GS-based diets (Tables 5 and 6 ). Forage type had no effect on total cis-MUFA (Table 5) and most 18:2 isomers (Table 7), although cis-11 18:1, cis-12 18:1, cis-13 18:1, cis-16 18:1, cis-11 20:1, and cis-9,cis-12 18:2 were higher $(P$ $<0.05$ ) on MS relative to GS (Tables 6 and 7 ), and cis-9 10:1, cis-9 12:1, and cis-9 14:1 were lower $(P<$ 0.05 ; Table 5). Concentrations of 20:3n-3 $(P<0.024)$, 20:5n-3 $(P<0.020)$, and $22: 2 \mathrm{n}-6(P<0.001)$ were higher in milk fat from cows fed the GS-based diets than the MS-based diets (Table 5). Total n-6 PUFA concentrations in milk fat were higher with MS-based $\operatorname{diets}(P=0.001)$.

\section{Effect of Extruded Linseed Supplementation on Milk FA Composition}

Including ELS in the diets lowered total milk SFA $(P=0.055$, Table 5). Milk fat concentrations of 16:0 $(P=0.012), 17: 0(P=0.009), 18: 0$ iso $(P=0.052)$,

Table 4. Effects of extruded linseed supplementation and dietary forage source on methane production and respiratory exchange of lactating dairy cows

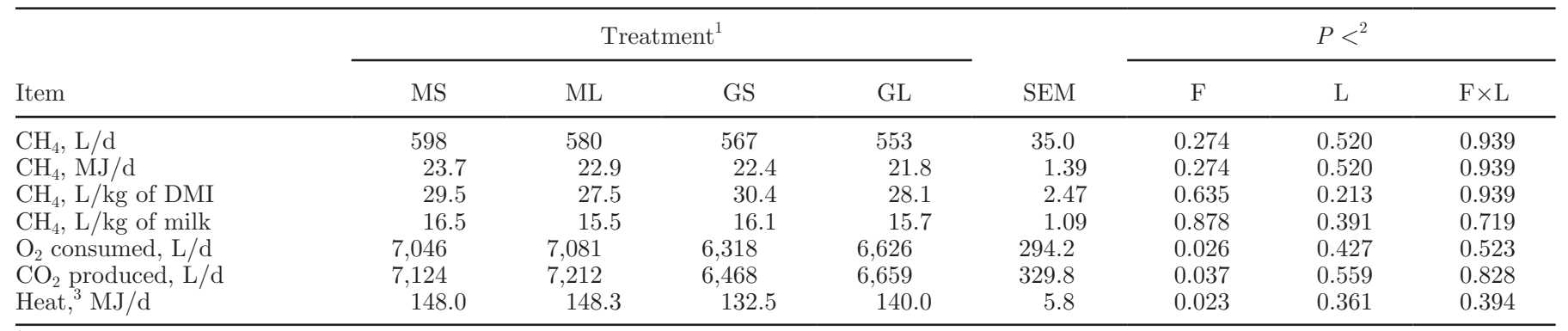

${ }^{1}$ Maize silage-based TMR (MS), maize silage-based TMR with extruded linseed (ML), grass silage-based TMR (GS), grass silage-based TMR with extruded linseed (GL).

${ }^{2}$ Probability for the effect of forage $(F)$, extruded linseed $(\mathrm{L})$, or their interaction $(\mathrm{F} \times \mathrm{L})$.

${ }^{3}$ Calculated based on respiratory exchange and methane production. 
and 24:0 $(P=0.022)$ were lower and 18:0 $(P=0.039)$ and 19:0 $(P=0.005)$ were higher when ELS was fed. Concentrations of cis-9 16:1 $(P=0.020)$ were lower and cis-16 18:1 $(P=0.014)$ and cis-7 19:1 $(P=0.025)$ were higher when ELS was fed.

Including ELS in the diet increased trans MUFA ( $P$ $=0.027)$ and total trans $(P=0.030)$ isomer concentrations compared with nonlinseed diets (Table 5). This change in trans profile was characterized by a greater $(P$ $=0.024$ ) total trans 18:1 isomer concentration (Tables 5 and 6) in milk fat when ELS was fed: trans-11 16:1 $(P=0.063)$ and trans-13+14 18:1 $(P=0.002)$, trans -15 18:1 $(P=0.0002)$, and trans-16 18:1 $(P<0.001)$. Similarly, ELS supplementation increased $(P<0.001)$ total non-CLA trans 18:2 isomers compared with nonlinseed diets (Table 7) by increasing cis-9,trans-12 18:2 ( $P=$ $0.02)$, cis-9,trans-13 18:2 $(P<0.001)$, trans-9, cis-12 18:2 $(P=0.008)$, trans-11,cis-15 18:2 $(P<0.001)$, and trans-12,cis-15 18:2 $(P=0.028)$. No effect of ELS was seen in total cis-MUFA concentrations $(P>0.05$, Table 5), although cis-12 18:1 $(P<0.021)$ and cis-16 18:1 $(P<0.014)$ concentrations were higher when ELS was fed. No interactions between forage type and ELS were shown in trans 18:1 or 18:2 isomers $(P>0.05$; Tables 5,6 , and 7), with the exception of trans-5 18:1 $(P=$ 0.016, Table 6) and cis-9,trans-12 18:2 $(P=0.055)$, cis-9,trans-13 18:2 $(P=0.082)$, and cis-10,trans-14 18:2 $(P=0.024$, Table 7$)$.

Milk fat concentrations of n-3 PUFA were higher $(P$ $<0.001$ ) with ELS supplementation (Table 5), mainly due to increases in 18:3n-3 $(P<0.001)$ and $20: 5 \mathrm{n}-3(P$ $=0.025)$. In contrast, 18:3n-6 $(P=0.036), 20: 3 \mathrm{n}-6(P$ $=0.034), 22: 4 \mathrm{n}-6(P=0.028)$, and $22: 2 \mathrm{n}-6(P<0.095)$ concentrations were lower in milk fat when ELS was fed, although no effect was observed on total n-6 PUFA concentrations $(P>0.10$, Table 5$)$.

\section{DISCUSSION}

\section{Intake and Milk Yield and Composition}

Silage type significantly influences lactation performance, with increases in DMI and milk yield often observed as MS replaces GS in mixed forage diets (O'Mara et al., 1998; Kliem et al., 2008). In the present study, DMI was greater when higher MS diets were fed, which was associated with a numerical increase $(1.2 \mathrm{~kg} / \mathrm{d})$ in milk yield and reduction $(3.2 \mathrm{~g} / \mathrm{kg})$ in milk fat concentration. However, as reported previously (O'Mara et al., 1998; Kliem et al., 2008), milk yield per kilogram of DMI was numerically lower for higher MS diets.

No effect of ELS was observed on DMI or milk yield. Supplemental dietary lipid has been shown to increase milk yield (Chilliard and Ferlay, 2004), but the re- sponses are inconsistent across studies (Grainger and Beauchemin, 2011). This is in part due to differences in experimental design, diet composition, and the type of fat fed, as well as stage of lactation (Grainger and Beauchemin, 2011). For example, feeding extruded flax seed reduced milk yield in late lactation cows (Gonthier et al., 2005), whereas feeding supplemental lipid may be more likely to increase milk yield in early lactation, depending on the basal diet and type of lipid fed (Grainger and Beauchemin, 2011). Increased concentrations of readily available lipid in the rumen can be detrimental to normal rumen function and can impair fiber digestion and milk fat synthesis. In previous studies, supplemental ELS reduced milk yield, milk fat concentration, or both (Martin et al., 2008; Kliem et al., 2009), yet in contrast, Hurtaud et al. (2010) reported an increase in milk yield following ELS supplementation. The lack of an effect of ELS in the present study may be due to the relatively low level of ELS inclusion in the diet and the stage of lactation of the cows at the initiation of the trial.

\section{Effects of Forage Type and Extruded Linseed on Methane Production}

We observed no effect of dietary forage type on methane production or yield. As noted previously, studies have found that greater concentrations of starch and lower concentrations of NDF in rations fed to cattle reduce methane production or yield, or both (Mills et al., 2001; Aguerre et al., 2011; Grainger and Beauchemin, 2011). Similarly, replacing barley, alfalfa, or grass silage with MS (Hassanat et al., 2013; Benchaar et al., 2014; van Gastelen et al., 2015) has reduced methane yield for diets fed to lactating dairy cows, but the effects have been linear (van Gastelen et al., 2015), curvilinear (Hassanat et al., 2013), or variable over time/age in growing cattle (Staerfl et al., 2012). Basal diets for the present study were based on previous studies, where feeding higher MS diets reduced methane yield compared with higher GS diets for lactating dairy cows (Reynolds et al., 2010). The lower methane yield for higher MS diets was observed despite TMR starch and NDF concentrations being similar for higher MS and higher GS diets. As in the present study (Table 1), this was achieved in the study of Reynolds et al. (2010) by adding maize meal to the GS diets and adding molasses sugar beet feed to the MS diets. This suggests that the source of the starch and NDF, and the resulting rates of fermentation in the rumen, may also determine methane yield. In this regard, Moe and Tyrrell (1979) reported that in addition to intakes of starch and NDF, their digestibility was also an important determinant of methane production by lactating and nonlactating 
Table 5. Effects of extruded linseed supplementation and dietary forage on milk FA composition ( $\mathrm{g} / 100 \mathrm{~g}$ of total FA)

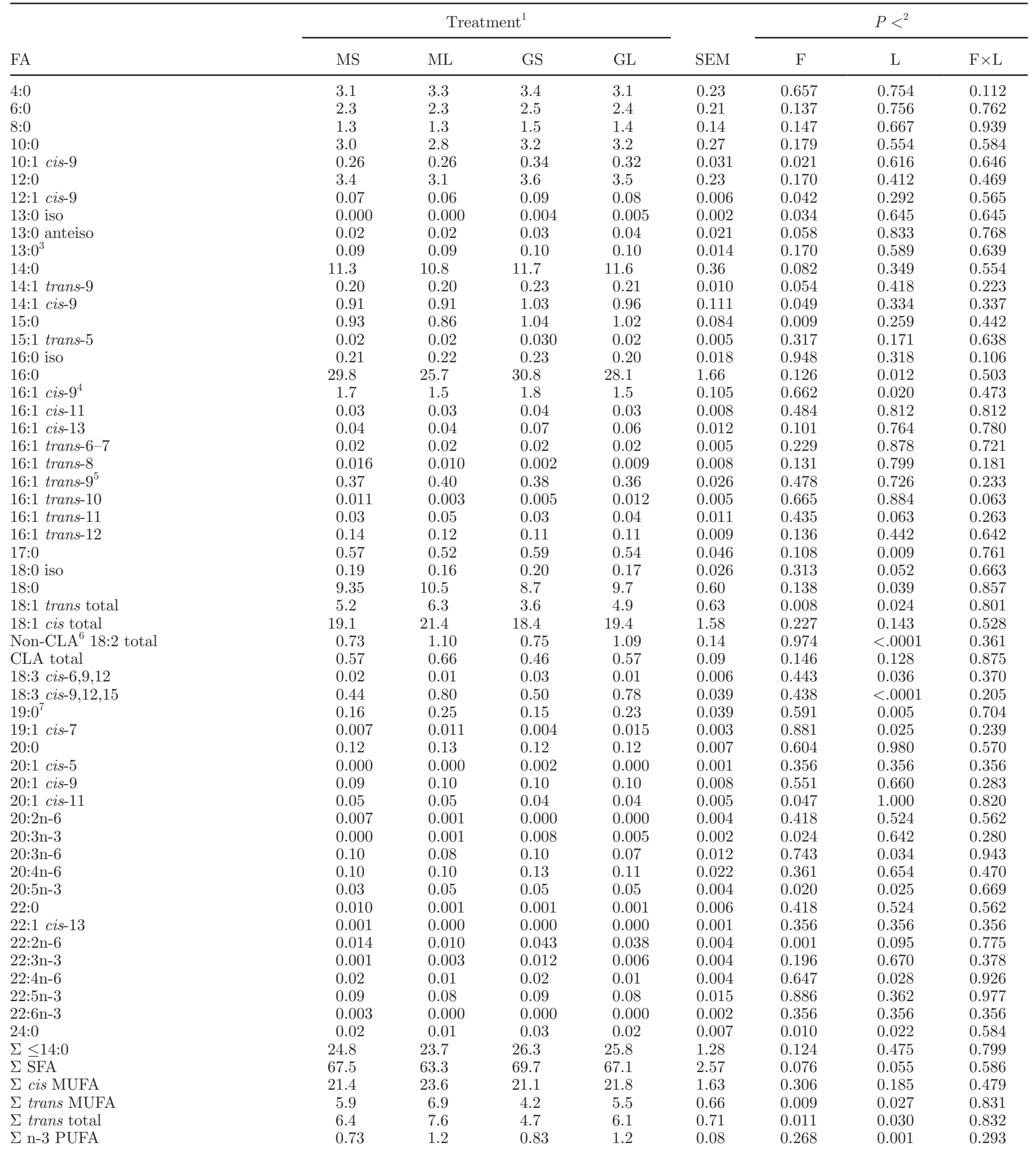


Table 5 (Continued). Effects of extruded linseed supplementation and dietary forage on milk FA composition (g/100 g of total FA)

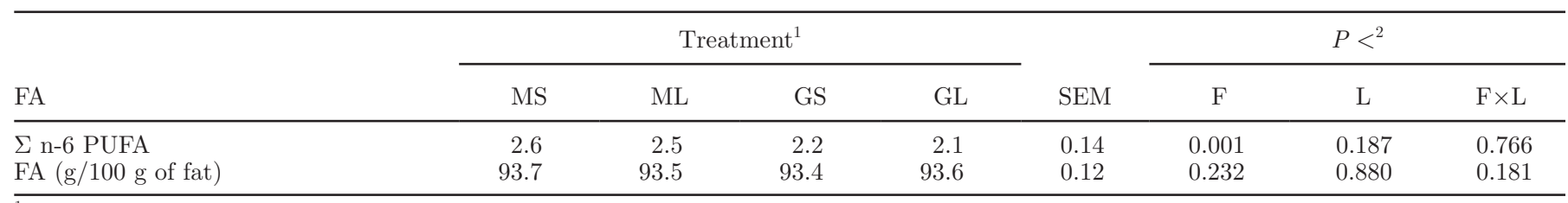

${ }^{1}$ Maize silage-based TMR (MS), maize silage-based TMR with extruded linseed (ML), grass silage-based TMR (GS), grass silage-based TMR with extruded linseed (GL).

${ }^{2}$ Probability for the effect of forage $(\mathrm{F})$, extruded linseed $(\mathrm{L})$, or their interaction $(\mathrm{F} \times \mathrm{L})$.

${ }^{3}$ Co-elutes with cis-9 12:1.

${ }^{4}$ Co-elutes with 17:0 anteiso.

${ }^{5}$ Co-elutes with 17:0 iso.

${ }^{6}$ All 18:2 isomers excluding CLA.

${ }^{7}$ Co-elutes with cis-15 18:1.

dairy cattle. Although diets were formulated to have equal concentrations of starch and NDF in the present study, starch concentration was higher in MS compared with GS diets, but NDF concentration was also higher in the MS diets. This was due to differences in the NDF and starch concentrations of the GS and MS fed during the study compared with the concentration measured when treatment diets were formulated. Therefore, the higher concentration of NDF in the MS diets may have counteracted negative effects of higher starch concentration and MS composition per se on methane yield compared with GS diets. In addition, the difference in DMI between GS and MS diets was greater in the previous study (Reynolds et al., 2010), which may also explain differences in the response of methane yield to forage type between the present and previous study.
In the present study, no significant effect was found of feeding ELS at $50 \mathrm{~g} / \mathrm{kg}$ of diet DM on methane production or yield. Feeding linseed oil to sheep has previously been shown to reduce methane production (Blaxter and Czerkawski, 1966; Clapperton, 1974). Furthermore, feeding linseed oil as extruded or crushed linseed (or flaxseed) decreased both methane production and methane yield of lactating dairy cows (Beauchemin et al., 2009; Martin et al., 2008). Indeed, supplemental dietary fat typically reduces methane yield of ruminants (Beauchemin et al., 2008; Grainger and Beauchemin, 2011). The effects of supplemental fat on methane yield are multifactorial, but are dominated by the provision of a source of digestible energy that is not fermented in the rumen (Grainger and Beauchemin, 2011). Based on results of a meta-analysis of published results, Grainger

Table 6. Effects of extruded linseed supplementation and dietary forage on milk 18:1 isomer composition (g/100 g of total FA)

\begin{tabular}{|c|c|c|c|c|c|c|c|c|}
\hline \multirow[b]{2}{*}{ FA } & \multicolumn{4}{|c|}{ Treatment $^{1}$} & \multirow[b]{2}{*}{ SEM } & \multicolumn{3}{|c|}{$P<^{2}$} \\
\hline & MS & ML & GS & GL & & $\mathrm{F}$ & $\mathrm{L}$ & $\mathrm{F} \times \mathrm{L}$ \\
\hline cis-9 $18: 1^{3}$ & 17.4 & 19.4 & 17.2 & 17.9 & 1.40 & 0.371 & 0.189 & 0.482 \\
\hline cis-11 18:1 & 0.75 & 0.73 & 0.54 & 0.58 & 0.123 & 0.016 & 0.922 & 0.598 \\
\hline cis-12 18:1 & 0.46 & 0.57 & 0.29 & 0.41 & 0.048 & 0.005 & 0.021 & 0.935 \\
\hline cis-13 18:1 & 0.12 & 0.12 & 0.09 & 0.11 & 0.019 & 0.046 & 0.180 & 0.422 \\
\hline cis-16 18:1 & 0.05 & 0.08 & 0.03 & 0.04 & 0.015 & 0.003 & 0.014 & 0.408 \\
\hline trans-5 18:1 & 0.030 & 0.015 & 0.004 & 0.018 & 0.005 & 0.044 & 0.849 & 0.016 \\
\hline trans- $6,-7,-8$ 18:1 & 0.39 & 0.45 & 0.23 & 0.30 & 0.058 & 0.004 & 0.103 & 0.791 \\
\hline trans-9 18:1 & 0.33 & 0.38 & 0.21 & 0.27 & 0.063 & 0.045 & 0.268 & 0.888 \\
\hline trans-10 18:1 & 0.92 & 0.88 & 0.41 & 0.54 & 0.313 & 0.038 & 0.784 & 0.624 \\
\hline trans-11 18:1 & 1.30 & 1.60 & 0.86 & 1.18 & 0.194 & 0.056 & 0.114 & 0.947 \\
\hline trans-13-14 18:1 & 0.93 & 1.25 & 0.81 & 1.09 & 0.190 & 0.060 & 0.002 & 0.722 \\
\hline trans-15 18:1 & 0.54 & 0.72 & 0.50 & 0.66 & 0.063 & 0.058 & 0.002 & 0.746 \\
\hline trans-16 $18: 1^{4}$ & 0.46 & 0.63 & 0.40 & 0.58 & 0.049 & 0.028 & 0.001 & 1.000 \\
\hline
\end{tabular}

${ }^{1}$ Maize silage-based TMR (MS), maize silage-based TMR with extruded linseed (ML), grass silage-based TMR (GS), grass silage-based TMR with extruded linseed (GL).

${ }^{2}$ Probability for the effect of forage $(\mathrm{F})$, extruded linseed $(\mathrm{L})$, or their interaction $(\mathrm{F} \times \mathrm{L})$.

${ }^{3}$ Co-elutes with cis-10 18:1.

${ }^{4}$ Co-elutes with cis-14 18:1. 
Table 7. Effects of extruded linseed supplementation and dietary forage on milk 18:2 isomer composition (g/100 g of total FA)

\begin{tabular}{|c|c|c|c|c|c|c|c|c|}
\hline \multirow[b]{2}{*}{ FA } & \multicolumn{4}{|c|}{ Treatment $^{1}$} & \multirow[b]{2}{*}{ SEM } & \multicolumn{3}{|c|}{$P<^{2}$} \\
\hline & MS & ML & GS & GL & & $\mathrm{F}$ & $\mathrm{L}$ & $\mathrm{F} \times \mathrm{L}$ \\
\hline cis-9,cis-12 18:2 & 2.30 & 2.20 & 1.80 & 1.70 & 0.14 & 0.002 & 0.377 & 0.759 \\
\hline cis-9,cis-15 $18: 2$ & 0.05 & 0.05 & 0.06 & 0.05 & 0.010 & 0.424 & 0.475 & 0.279 \\
\hline cis-9,trans-12 18:2 & 0.06 & 0.06 & 0.04 & 0.06 & 0.009 & 0.140 & 0.020 & 0.055 \\
\hline cis-9,trans-13 18:2 & 0.21 & 0.38 & 0.23 & 0.34 & 0.074 & 0.324 & 0.001 & 0.082 \\
\hline cis-9,trans-14 18:2 & 0.11 & 0.16 & 0.11 & 0.15 & 0.029 & 0.597 & 0.001 & 0.417 \\
\hline cis-10,trans-14 18:2 & 0.15 & 0.11 & 0.13 & 0.14 & 0.009 & 0.441 & 0.145 & 0.024 \\
\hline trans-9, cis-12 18:2 & 0.02 & 0.03 & 0.01 & 0.02 & 0.004 & 0.125 & 0.008 & 0.452 \\
\hline trans-11, cis-15 18:2 & 0.06 & 0.19 & 0.09 & 0.20 & 0.026 & 0.320 & 0.001 & 0.518 \\
\hline trans-12, cis-15 18:2 & 0.03 & 0.03 & 0.02 & 0.04 & 0.006 & 0.593 & 0.028 & 0.302 \\
\hline trans-11,trans-15 18:2 & 0.05 & 0.05 & 0.04 & 0.05 & 0.006 & 0.140 & 0.715 & 0.472 \\
\hline
\end{tabular}

${ }^{1}$ Maize silage-based TMR (MS), maize silage-based TMR with extruded linseed (ML), grass silage-based TMR (GS), grass silage-based TMR with extruded linseed (GL).

${ }^{2}$ Probability for the effect of forage $(\mathrm{F})$, extruded linseed $(\mathrm{L})$, or their interaction $(\mathrm{F} \times \mathrm{L})$.

and Beauchemin (2011) concluded that increasing dietary inclusion of fat caused a linear reduction in methane yield and that within what were considered to be practical levels of dietary fat inclusion, no difference was apparent in the magnitude of the effect of different types and forms of fat supplements on methane yield of cattle or sheep. Based on their analysis of data in cattle, methane yield was reduced by $1 \mathrm{~g} / \mathrm{kg}$ of diet DM for every $10 \mathrm{~g} / \mathrm{kg}$ increase in dietary fat concentration on a DM basis. In the present study, the average increase in dietary FA concentration measured $(8.1 \mathrm{~g} / \mathrm{kg}$ of DM) was associated with a numerical reduction in average methane yield $(-2.15 \mathrm{~g} / \mathrm{kg}$ of $\mathrm{DM})$, which is more than the decrease predicted based on the data summarized by Grainger and Beauchemin (2011). This suggests that the lack of a significant effect of supplemental ELS in the present study was in part due to the relatively low amount of fat inclusion in the diets. In this regard, the amount fed was approximately twice the amount recommended in UK commercial practice, which would be expected to have only a small effect on methane yield based on the numerical reduction observed in the present study.

A relationship between concentrations of several FA in milk fat and methane production or yield by lactating dairy cows has been reported (Chilliard et al., 2009; Dijkstra et al., 2011; Mohammed et al., 2011). Chilliard et al. (2009) reported that the large decrease in methane production of dairy cows when linseed oil was fed (Martin et al., 2008) was associated with a decrease in 8:0 and 16:0 and an increase in total 18 carbon FA and cis-9, trans-13 18:2 concentrations in milk fat. We observed a significant increase in cis-9, trans-13 and decrease in 16:0 when ELS was fed that was not associated with a significant effect of ELS on methane production. In addition, no effect was observed of
ELS at the levels provided on 8:0 concentrations. As discussed previously, these discrepancies may reflect differences in the amounts of ELS fed compared with the study of Martin et al. (2008), where supplemental ELS increased diet ether extract concentration from 26 to $70 \mathrm{~g} / \mathrm{kg}$ of DM. Moreover, the relationships between milk fat concentrations of individual FA and methane production observed by Chilliard et al. (2009) may be specific to the dietary treatments used in their study (supplemental linseed oil). A recent meta-analysis of data from cows fed a variety of diets found no relationship between milk fat concentration of 8:0 or total 18 carbon FA and methane production (Williams et al., 2014), although van Lingen et al. (2014) recently reported a significant positive relationship between 8:0 and methane yield in lactating dairy cows.

\section{Effects of Forage Type and Extruded Linseed on Milk FA Concentration}

Previous studies have shown that forage type and oil supplements can influence milk FA composition (Kliem et al., 2008; Samková et al., 2009; Hurtaud et al., 2010; Sterk et al., 2011). Supplementation of diets with PUFA-rich oil sources such as ELS is thought to inhibit de novo milk FA synthesis of short- (4:0-10:0) and medium- (12:0-16:0) chain SFA in the mammary gland (Palmquist et al., 1993), thus reducing total SFA. Palmquist et al. (1993) suggested that this is due to an increased supply of dietary- and ruminally derived unsaturated FA that compete for esterification with short-chain FA synthesized in the mammary gland. Another possible mechanism is the inhibitory effect of trans-18 isomers produced during biohydrogenation on the de novo synthesis of short- and medium-chain SFA (Chilliard et al., 2001). Previous studies have confirmed 
this relationship and corroborate the significantly lower 16:0 concentrations seen in the present study (Glasser et al., 2008). However, we observed no significant differences in the amounts of short-chain FA following ELS supplementation, which contradicts previous findings (Glasser et al., 2008). Chilliard and Ferlay (2004) suggested that short-chain FA are not affected by lipid supplementation. Instead, it is argued that short-chain FA can be partially synthesized by pathways independent to medium-chain FA, where the former does not rely on acetyl-CoA carboxylase (Palmquist and Jenkins, 1980). This may explain why ELS and forage type had very little effect on the short-chain FA and only a small effect on medium-chain FA. An additional explanation for this may also be due to the low linseed oil inclusion level in comparison with other studies, which have fed up to $1 \mathrm{~kg}$ of linseed oil.

Chilliard et al. (2001) suggested that evidence was insufficient to confirm the effect of forage type, as a total mixed ration, on milk FA composition but that MS may increase de novo short-chain FA synthesis. To date, few studies have addressed this, although Kliem et al. (2008) proposed that MS may increase de novo short- and medium-chain FA production via an increased supply of acetate to the mammary gland. The MS had little effect on these FA in the present study, in part reflecting the relatively small differences in forage type $(250 \mathrm{~g} / \mathrm{kg}$ of diet DM). However, van Gastelen et al. (2015) also observed no effect of incremental replacement of GS with MS on milk fat concentrations of short- and medium-chain FA, apart from a linear reduction in 4:0.

Consistent with previous studies, increases in both 18:0 and total trans isomers concentrations in milk fat were observed when ELS was fed (Kliem et al., 2009; Hurtaud et al., 2010), as well as increased concentrations of trans FA isomers for the MS diets (Kliem et al., 2008). Inclusion of dietary oils (Collomb et al., 2004) and particularly unprotected oils (Loor et al., 2005) leads to a characteristic increase in trans and CLA isomers due to exposure of unsaturated FA to rumen microflora (Chilliard et al., 2001; Shingfield et al., 2005). As observed in the present study, Chilliard et al. (2009) identified trans-13+14 18:1, cis-9,trans-13 18:2 and trans-11,cis-15 18:2 as intermediates of biohydrogenation of the ELS diets. Although the MS diets had higher concentrations of cis-9 18:1 than GS, milk fat cis-9 18:1 did not significantly increase. Similarly, despite a higher intake of 18:0 from MS compared with GS, milk fat 18:0 was not significantly higher following the MS diet. Our observed effect of forage type on milk fat trans-18:1 isomers has been confirmed in other studies (Shingfield et al., 2005) and has been attributed to differences in forage digestibility (O'Mara et al., 1998).
Additionally, feeding a high MS diet, rich in n-6 PUFA and starch, leads to characteristic increases in trans-10 18:1 (Kliem et al., 2008), which is consistent with our findings.

Linseed supplementation has been used in previous studies to not only reduce milk SFA, but also increase n-3 PUFA. Although, our results showed that this strategy did increase total n-3 PUFA, whether this increase would translate to an important health benefit to the consumer is questionable. The present study showed a significant increase in eicosapentaenoic acid (EPA; MS: 34 to $45 \mathrm{mg} / 100 \mathrm{~g}$ of total FA, GS: 45 to $53 \mathrm{mg} / 100$ $\mathrm{g}$ of total FA) after ELS supplementation. Based on the enrichment of EPA seen in the present study, a $100-\mathrm{mL}$ glass of this milk would only contribute up to $0.4 \%$ of the $450-\mathrm{mg}$ daily intake for long-chain PUFA recommended for UK adults (Givens, 2008). Although not substantial, these calculations do not include other n-3 FA and dairy products. In addition, supplementation of the dairy cow's diet with ELS may represent a sustainable alternative to the use of marine oils, which have environmental and economic implications.

Growing public interest in lowering SFA consumption to improve human health means that any decrease in milk SFA concentrations following forage and lipid supplementation has public health incentives. Our study found only 3 minor interactions between forage type and ELS supplementation for the selected milk FA, which are in line with findings by Sterk et al. (2011). Whereas lipid supplementation, and possibly MS, provided potentially beneficial decreases in SFA, the current concerns linking trans FA to increased risk of CVD mean that the significantly higher total trans concentrations following both MS and ELS supplementation may counteract the beneficial decreases in SFA concentration. The question of whether ruminant trans are of similar risk to CVD as industrial trans remains largely unanswered (Bendsen et al., 2011). Nonetheless, the implementation of trans labeling suggests that increases should be minimized, and development of lipid protection technologies is required to minimize their production. Because current UK intakes of long-chain n-3 PUFA are inadequate (Givens, 2008), enrichment of milk in this way may have long-term implications for human health. Nevertheless, it is questionable whether the magnitude of the changes in long-chain PUFA concentrations seen in this study would produce a meaningful effect on health on a population level.

\section{CONCLUSIONS}

The present study demonstrated that a relatively low inclusion level of oilseed (ELS) supplement can partially replace milk SFA with MUFA and PUFA, includ- 
ing long-chain PUFA, thereby offering a sustainable means of modifying milk FA composition, irrespective of whether MS or GS diets are fed. Methane production was not significantly affected, but numerical reductions observed were in line with predictions based on the relatively low amount of linseed oil fed. In contrast to other studies where replacing GS with MS increased starch and decreased NDF in the diets fed, replacing GS with MS in diets formulated for similar NDF and starch concentrations did not reduce methane production or yield, in part due to a lower NDF concentration in the GS than expected. Decreases in SFA and increases in unsaturated FA concentrations in milk fat were observed that if considered at a population level, including implications for other dairy products and dairy-containing foods, may contribute to a lower risk of CVD. However, changes in beneficial PUFA and detrimental SFA and trans FA need to be balanced, while avoiding any effects on cow performance. These priorities remain a challenge to the agriculture and food sectors and require further exploration.

\section{ACKNOWLEDGMENTS}

Funding by Marks and Spencer Plc (London, UK) is gratefully acknowledged. The contributions of staff at the Centre for Dairy Research of the University of Reading for the care and management of animals used and for technical assistance during the study is also much appreciated.

\section{REFERENCES}

Aguerre, M. J., M. A. Wattiaux, J. M. Powell, G. A. Broderick, and C. Arndt. 2011. Effect of forage-to-concentrate ratio in dairy cow diets on emission of methane, carbon dioxide, and ammonia, lactation performance, and manure excretion. J. Dairy Sci. 94:30813093. http://dx.doi.org/10.3168/jds.2010-4011.

Beauchemin, K. A., M. Kreuzer, F. O'Mara, and T. A. McAllister. 2008. Nutritional management for enteric methane abatement: A review. Aust. J. Exp. Agric. 48:21-27. http://dx.doi.org/10.1071/ EA07199.

Beauchemin, K. A., S. M. McGinn, C. Benchaar, and L. Holtshausen. 2009. Crushed sunflower, flax, or canola seeds in lactating dairy cow diets: Effects on methane production, rumen fermentation, and milk production. J. Dairy Sci. 92:2118-2127. http://dx.doi. org/10.3168/jds.2008-1903.

Benchaar, C., F. Hassanat, R. Gervais, P. Y. Chouinard, H. V. Petit, and D. I. Massé. 2014. Methane production, digestion, ruminal fermentation, nitrogen balance, and milk production of cows fed corn silage- or barley silage-based diets. J. Dairy Sci. 97:961-974. http://dx.doi.org/10.3168/jds.2013-7122.

Bendsen, N. T., R. Christensen, E. M. Bartels, and A. Astrup. 2011. Consumption of industrial and ruminant trans fatty acids and risk of coronary heart disease: A systematic review and meta-analysis of cohort studies. Eur. J. Clin. Nutr. 65:773-783. http://dx.doi. org/10.1038/ejcn.2011.34.

Blaxter, K. L., and J. Czerkawski. 1966. Modifications of methane production of the sheep by supplementation of its diet. J. Sci. Food Agric. 17:417-421. http://dx.doi.org/10.1002/jsfa.2740170907.
Chilliard, Y., and A. Ferlay. 2004. Dietary lipids and forages interactions on cow and goat milk fatty acid composition and sensory properties. Reprod. Nutr. Dev. 44:467-492. http://dx.doi. org/10.1051/rnd:2004052.

Chilliard, Y., A. Ferlay, and M. Doreau. 2001. Effect of different types of forages, animal fat or marine oils in cow's diet on milk fat secretion and composition, especially conjugated linoleic acid (CLA) and polyunsaturated fatty acids. Livest. Prod. Sci. 70:31-48.

Chilliard, Y., C. Martin, J. Rouel, and M. Doreau. 2009. Milk fatty acids in dairy cows fed whole crude linseed, extruded linseed, or linseed oil, and their relationship with methane output. J. Dairy Sci. 92:5199-5211. http://dx.doi.org/10.3168/jds.2009-2375.

Clapperton, J. L. 1974. The effect of trichloroacetamide, chloroform and linseed oil given into the rumen of sheep on some of the endproducts of rumen digestion. Br. J. Nutr. 32:155-161. http:// dx.doi.org/10.1079/BJN19740065.

Collomb, M., R. Sieber, and U. Bütikofer. 2004. CLA isomers in milk fat from cows fed diets with high levels of unsaturated fatty acids. Lipids 39:355-364.

Dijkstra, J., S. M. van Zijderveld, J. A. Apajalahti, A. Bannink, W. J. J. Gerrits, J. R. Newbold, H. B. Perdok, and H. Berends. 2011. Relationships between methane production and milk fatty acid profiles in dairy cattle. Anim. Feed Sci. Technol. 166:590-595. http://dx.doi.org/10.1016/j.anifeedsci.2011.04.042.

Ferlay, A., B. Martin, P. Pradel, J. B. Coulon, and Y. Chilliard. 2006 Influence of grass-based diets on milk fatty acid composition and milk lipolytic system in Tarentaise and Montbéliarde cow breeds. J. Dairy Sci. 89:4026-4041.

Givens, D. I. 2008. Session 4: Challenges facing the food industry in innovating for health Impact on CVD risk of modifying milk fat to decrease intake of SFA and increase intake of cis-MUFA. Proc. Nutr. Soc. 67:419-427. http://dx.doi.org/10.1017/ S0029665108008707.

Givens, D. I., K. E. Kliem, D. J. Humphries, K. J. Shingfield, and R. Morgan. 2009. Effect of replacing calcium salts of palm oil distillate with rapeseed oil, milled or whole rapeseeds on milk fatty-acid composition in cows fed maize silage-based diets. Animal 3:10671074. http://dx.doi.org/10.1017/S175173110900442X.

Glasser, F., A. Ferlay, and Y. Chilliard. 2008. Oilseed lipid supplements and fatty acid composition of cow milk: A meta-analysis. J. Dairy Sci. 91:4687-4703. http://dx.doi.org/10.3168/jds.20080987.

Gonthier, C., A. F. Mustafa, D. R. Ouellet, P. Y. Chouinard, R. Berthiaume, and H. V. Petit. 2005. Feeding micronized and extruded flaxseed to dairy cows: Effects on blood parameters and milk fatty acid composition. J. Dairy Sci. 88:748-756.

Grainger, C., and K. A. Beauchemin. 2011. Can enteric methane emissions from ruminants be lowered without lowering their production? Anim. Feed Sci. Technol. 166-167:308-320. http://dx.doi. org/10.1016/j.anifeedsci.2011.04.021.

Hassanat, F., R. Gervais, C. Julien, D. I. Massé, A. Lettat, P. Y. Chouinard, H. V. Petit, and C. Benchaar. 2013. Replacing alfalfa silage with corn silage in dairy cow diets: Effects on enteric methane production, ruminal fermentation, digestion, $\mathrm{N}$ balance, and milk production. J. Dairy Sci. 96:4553-4567. http://dx.doi. org/10.3168/jds.2012-6480.

Hurtaud, C., F. Faucon, S. Couvreur, and J. L. Peyraud. 2010. Linear relationship between increasing amounts of extruded linseed in dairy cow diet and milk fatty acid composition and butter properties. J. Dairy Sci. 93:1429-1443. http://dx.doi.org/10.3168/ jds.2009-2839.

Kliem, K. E., P. C. Aikman, D. J. Humphries, R. Morgan, K. J. Shingfield, and D. I. Givens. 2009. Effect of replacing calcium salts of palm oil distillate with extruded linseeds on milk fatty acid composition in Jersey and Holstein cows. Animal 3:1754-1762. http:// dx.doi.org/10.1017/S1751731109990723.

Kliem, K. E., R. Morgan, D. J. Humphries, K. J. Shingfield, and D. I. Givens. 2008. Effect of replacing grass silage with maize silage in the diet on bovine milk fatty acid composition. Animal 2:18501858. http://dx.doi.org/10.1017/S1751731108003078. 
Kliem, K. E., C. K. Reynolds, D. J. Humphries, R. M. Kirkland, C. E. S. Barratt, K. M. Livingstone, and D. I. Givens. 2013. Incremental effect of a calcium salt of cis-monounsaturated fatty acids supplement on milk fatty acid composition in cows fed maize silage-based diets. J. Dairy Sci. 96:3211-3221. http://dx.doi.org/10.3168/ jds.2012-6211.

Loor, J. J., A. Ferlay, A. Ollier, M. Doreau, and Y. Chilliard. 2005. Relationship among trans and conjugated fatty acids and bovine milk fat yield due to dietary concentrate and linseed oil. J. Dairy Sci. 88:726-740.

Martin, C., J. Rouel, J. P. Jouany, M. Doreau, and Y. Chilliard. 2008. Methane output and diet digestibility in response to feeding dairy cows crude linseed, extruded linseed, or linseed oil. J. Anim. Sci. 86:2642-2650. http://dx.doi.org/10.2527/jas.2007-0774.

Mills, J. A. N., J. Dijkstra, A. Bannink, S. B. Cammell, E. Kebreab, and J. France. 2001. A mechanistic model of whole-tract digestion and methanogenesis in the lactating dairy cow: Model development, evaluation and application. J. Anim. Sci. 79:1584-1597.

Moe, P. W., and H. F. Tyrrell. 1979. Methane production in dairy cows. J. Dairy Sci. 62:1583-1586. http://dx.doi.org/10.3168/jds. S0022-0302(79)83465-7.

Mohammed, R., S. M. McGinn, and K. A. Beauchemin. 2011. Prediction of enteric methane output from milk fatty acid concentrations and rumen fermentation parameters in dairy cows fed sunflower, flax, or canola seeds. J. Dairy Sci. 94:6057-6068. http://dx.doi. org/10.3168/jds.2011-4369

Nielsen, T. S., K. Sejrsen, H. R. Andersen, P. Lund, and E. M. Straarup. 2006. Effect of silage type and energy concentration on conjugated linoleic acid (CLA) in milk fat from dairy cows. Anim. Feed Sci. Technol. 13:697-700.

O'Mara, F. P., J. J. Fitzgerald, J. J. Murphy, and M. Rath. 1998 The effect on milk production of replacing grass silage with maize silage in the diet of dairy cows. Livest. Prod. Sci. 55:79-87.

Palmquist, D. L., A. D. Beaulieu, and D. M. Barbano. 1993. Feed and animal factors influencing milk fat composition. J. Dairy Sci. 76:1753-1771. http://dx.doi.org/10.3168/jds.S00220302(93)77508-6.

Palmquist, D. L., and T. C. Jenkins. 1980. Fat in lactation rations . J. Dairy Sci. 63:1-14. http://dx.doi.org/10.3168/jds.S00220302(80)82881-5.

Reynolds, C. K., L. A. Crompton, J. A. N. Mills, D. J. Humphries, P. Kirton, A. E. Relling, T. H. Misselbrook, D. R. Chadwick, and D. I. Givens. 2010. Effects of diet protein level and forage source on energy and nitrogen balance and methane and nitrogen excretion in lactating dairy cows. Pages 463-464 in Proceedings of the 3rd International Symposium on Energy and Protein Metabolism. G. M. Corvetto, ed. EAAP Publ. No. 127, Wageningen Academic Publishers, Wageningen, the Netherlands.

Reynolds, C. K., D. J. Humphries, P. Kirton, M. Kindermann, S. Duval, and W. Steinberg. 2014. Effects of 3-nitrooxypropanol on methane emission, digestion, and energy and nitrogen balance of lactating dairy cows. J. Dairy Sci. 97:3777-3789. http://dx.doi org/10.3168/jds.2013-7397.

Samková, E., M. Pešek, J. Špička, T. Pelikánová, and O. Hanuš. 2009. The effect of feeding diets markedly differing in the proportion of grass and maize silages on bovine milk fat composition. Czech J. Anim. Sci. 54:93-100.

Shingfield, K. J., C. K. Reynolds, B. Lupoli, V. Toivonen, M. P. Yurawecz, P. Delmonte, J. M. Griinari, A. S. Grandison, and D. E. Beever. 2005. Effect of forage type and proportion of concentrate in the diet on milk fatty acid composition in cows given sunflower oil and fish oil. Anim. Sci. 80:225-238. http://dx.doi. org/10.1079/ASC41820225.

Staerfl, S. M. J. O. Zeitz, M. Kreuzer, and C. R. Soliva. 2012. Methane conversion rate of bulls fattened on grass or maize silage as compared with IPCC default values, and the long-term methane mitigation efficiency of adding acacia tannin, garlic, maca and lupine. Agric. Ecosyst. Environ. 148:111-120.

Sterk, A., B. E. O. Johansson, H. Z. H. Taweel, M. Murphy, A. M. van Vuuren, W. H. Hendriks, and J. Dijkstra. 2011. Effects of forage type, forage to concentrate ratio, and crushed linseed supplementation on milk fatty acid profile in lactating dairy cows. J. Dairy Sci. 94:6078-6091. http://dx.doi.org/10.3168/jds.2011-4617.

van Gastelen, S., E. C. Antunes-Fernandes, K. A. Hettinga, G. Klop, S. J. J. Alferink, W. H. Hendriks, and J. Dijkstra. 2015. Enteric methane production, rumen volatile fatty acid concentrations, and milk fatty acid composition in lactating Holstein-Friesian cows fed grass silage- or corn silage-based diets. J. Dairy Sci. 98:1915-1927.

van Lingen, H. J., L. A. Crompton, W. H. Hendriks, C. K. Reynolds, and J. Dijkstra. 2014. Meta-analysis of relationships between methane production and milk fatty acid profile in dairy cattle. J. Dairy Sci. 97:7115-7132. http://dx.doi.org/10.3168/jds.20148268.

Williams, S. R. O., P. J. Moate, M. H. Deighton, M. C. Hannah, and W. J. Wales. 2014. Methane emissions of dairy cows cannot be predicted by the concentrations of C8:0 and total C18 fatty acids in milk. Anim. Prod. Sci. 54:1757-1761. http://dx.doi.org/10.1071/ AN14292. 